\title{
Accumulation of dietary fish fatty acids in the body fat reserves of some carnivorous fur-bearing animals
}

\author{
KIRSTI ROUVINEN, JAAKKo MÄKELÄ, TUOMO KIISKINEN and SEPPO NuMMELA
}

\begin{abstract}
Rouvinen, K., MÄ́kelä, J., KiISKınen, T. \& Nummela, S. 1992. Accumulation of dietary fish fatty acids in the body fat reserves of some carnivorous fur-bearing animals. Agric. Sci. Finl. 1: 483-489. (Agric. Res. Centre of Finland, Fur Farming Res. Sta., SF-69100 Kannus, Finland, Finnish Fur Breeders' Association, P.O.Box 5, SF-01601 Vantaa, Finland, Agric. Res. Centre of Finland, Inst. Anim. Prod., SF-31600 Jokioinen, Finland and Agric. Res. Centre of Finland, Centr. Lab., SF-31600 Jokioinen, Finland.)
\end{abstract}

\begin{abstract}
Body fat composition of the mink (Mustela vison), polecat (Mustela putorius), and the raccoon dog (Nyctereutes procyonoides) was studied. The animals were fed a wet diet, supplemented with $5 \%$ lard (LA) or fish oil (FO) for 5-6 months. At pelting, five animals per dietary group were sampled. Dietary levels of cetoleic (C22:1 $\omega 11)$, eicosapentaenoic (EPA, C20:5 $\omega 3$ ), and docosahexaenoic (DHA, C22:6 $\omega 3$ ) acids were 0.4, 0.3 , and $0.5 \%$ in the fat of the LA diet, and 7.6, 4.2 and $4.3 \%$ in the FO diet, respectively. In the FO diet, EPA and DHA accumulated especially in the liver and heart, while cetoleic acid showed the highest affinity to the heart muscle and subcutaneous fat. The highest levels of EPA were found in raccoon dogs and polecats fed the FO diet. The mean EPA levels ranged from $6.7-9.3 \%$ in the liver fat and $7.2-8.0 \%$ in the heart muscle fat. In the mink, the corresponding values were $2.7 \%$ and $3.9 \%$, respectively. DHA levels were the highest in the liver fat of the polecats, being $18.5 \%$ in the FO diet. In addition, the liver in raccoon dogs fed the FO diet (13.8\%) differed significantly from the mink $(9.4 \%)$. The differences in the accumulation of these long-chained marine fatty acids were apparently caused by species differences in the efficiency of their peroxisomal $\beta$-oxidation.
\end{abstract}

Key words: ferret, mink, polecat, raccoon dog, cetoleic acid, omega-3 fatty acids, liver, heart, subcutaneous fat

\section{Introduction}

In monogastric animals, dietary fat has a strong influence on the fatty acid composition of the tissues and organs. Feeding vegetable oils and fish oils to mink and blue foxes has been shown to increase the levels of linoleic and omega- 3 fatty acids, respectively, in the fat depots and the liver of the animals (ROUVINEN and KIISKINEN 1989, SKREDE and GULBRANDSEN 1985, SKREDE 1984, ÅHMAN 1965). In blue and silver foxes, feeding an abundance of fish fat is known to cause prominent accumulation of the typical fish fatty acids, i.e.

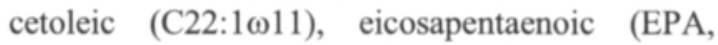

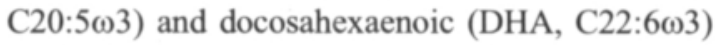
acids, in their subcutaneous fat, liver tissue and 
heart muscle (ROUVINEN 1991, RoUVINEN 1992). In the rat, feeding fish oil or high erucic acid $(\mathrm{C} 22: 1 \omega 9)$ rapeseed oil has been shown to cause lipid infiltration, cell destruction, local inflammatory reactions and fibrous scar tissue growth in the heart muscle (BEARE-Rogers 1977, KINSELLA 1987). Accumulation of these long-chained fatty acids in body tissues is apparently due to their impaired oxidation. The 20 or 22 carbon atomchained fatty acids should first be shortened in the peroxisomes to 16 or 18 carbon atom-fatty acids before they can be metabolized by the mitochondrial $\beta$-oxidation (OPSTVEDT 1984).

The present paper reports the effects of feeding lard or fish oil supplemented diets on the body fat composition of some farm-raised carnivorous furbearing animals, mink, polecat and the raccoon dog.

\section{Material and methods}

Mink (Mustela vison), polecats (Mustela putorius) and raccoon dogs (Nyctereutes procyonoides) were fed diets based on slaughterhouse offal, fish offal and cereals supplemented either with lard (LA) or fish oil (FO), at $5 \%$ in the diet. The animals used were all born during the spring of 1988 , and were raised according to normal fur farming practices at the Veikkola Research Farm of the Finnish Fur Breeders' Association, Kirkkonummi. The trial lasted from July until pelting during the autumn of 1988. Composition of the experimental diets is presented in Table 1. Feed samples for chemical analysis were taken on August 23rd, and on September 30th. Fatty acid composition was analyzed from feed samples taken on November 30th.

Five animals per dietary group were electrically executed for sampling on November 30th, 1988. At sampling, the age of the animals was approximately 6-7 months. The mink and polecats were all males, but the raccoon dogs included both sexes, two males and three females per group. The animals were weighed and sampled for liver fat analysis, and samples for fatty acid analysis were taken from
Table 1. Composition of experimental diets from weaning to pelting 1988. $\mathrm{LA}=$ lard diet, $\mathrm{FO}=$ fish oil diet.

Diet

\begin{tabular}{|c|c|c|}
\hline Ingredient, $\%$ & LA & $\mathrm{FO}$ \\
\hline Slaughterhouse offal ${ }^{a)}$ & 15 & 15 \\
\hline Fish offal & 30 & J \\
\hline Fish meal & 1 & \\
\hline Soybean meal & 0.5 & 0 \\
\hline Corn gluten & 1 & \\
\hline Blood meal & 1 & \\
\hline Cereals $^{\text {b) }}$ & 13 & 3 \\
\hline Vitamins $^{\mathrm{c})}$ & 1.5 & 1 \\
\hline Lard & 5 & \\
\hline Fish oil & - & \\
\hline Water & 32 & 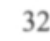 \\
\hline
\end{tabular}

a) LSO slaughterhouse, Forssa

b) cooked cereal: wheat $50 \%$ and barley $50 \%$.

c) 1 kg mixture contains: vitamin A, $500000 \mathrm{IU}$; vitamin $\mathrm{D}_{3}, 50000 \mathrm{IU}$; vitamin C, $6000 \mathrm{mg}$; vitamin E, $4000 \mathrm{mg}$; vitamin $\mathrm{K}, 10 \mathrm{mg}$; vitamin $\mathrm{B}_{1}, 1500 \mathrm{mg}$; vitamin $\mathrm{B}_{2}, 600$ $\mathrm{mg}$; vitamin $\mathrm{B}_{12}, 1 \mathrm{mg}$; choline, $2500 \mathrm{mg}$; pantothenic acid, $500 \mathrm{mg}$; nicotinic acid, $1000 \mathrm{mg}$; pyridoxin, $400 \mathrm{mg}$; folic acid, $50 \mathrm{mg}$; and biotin, $3 \mathrm{mg}$.

the rump region of the carcasses (subcutaneous fat), the liver and the heart. The weights of the sampled organs were also taken. The feed, tissue and fat samples were stored at $-30^{\circ} \mathrm{C}$ until analyzed between January 4th and March 13th, 1989.

The experimental diets were analyzed for dry matter (DM), ash, Kjeldahl nitrogen and crude fat. The analyses were performed by the Feed Laboratory of the Finnish Fur Breeders Association, Vaasa. Fatty acid composition of the diets and the tissue samples were determined in the Central Laboratory of the Agricultural Research Centre of Finland. The method employed is described in detail by RoUVINEN (1991). The liver fat content was determined by the method of MAXwell et al. (1980) at the laboratory of the Institute of Animal Production, Animal Nutrition Section, Jokioinen.

Statistical analysis was performed by the General Linear Models (GLM) procedure of the Statistical Analysis System (SAS 1988). The model used was as follows: 
$Y_{i j k}=\mu+S_{i}+D_{j}+S_{i j}+e_{i j k}$

where $\mu$ is the general mean, $\mathrm{S}_{\mathrm{i}}$ is the species effect $(i=1-3), \mathrm{D}_{\mathrm{j}}$ is the dietary effect $(j=1-2), \mathrm{SD}_{\mathrm{ij}}$ represents the species diet interaction and $\mathrm{e}_{\mathrm{ijk}}$ is the error term. Differentiation among the mean values was done by Duncan's multiple-range test. There were no statistical differences $(p>0.05)$ between sexes in the fatty acid composition of the tissue samples taken from the raccoon dogs, therefore the means given represent pooled data from both sexes.

\section{Results}

Chemical composition of the experimental diets was similar in lard (LA) and fish oil (FO) supplemented groups (Table 2). Dietary fat content was high, $27-30 \%$ in DM, which accounted for approximately $50 \%$ of the metabolizable energy in both dietary groups.

Dietary fatty acid composition showed a great difference between the lard and fish oil supplemented diets (Table 3). The lard diet contained more stearic (C18:0) and oleic (C18:1 $\omega 9)$ acids, but in the fish oil diet the content of cetoleic

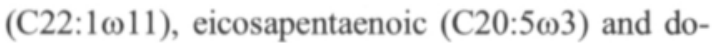

Table 2. Chemical composition of the diets during the growth period 1988. Diets sampled on Aug. 23rd and Sept. 30th. $\mathrm{LA}=$ lard, $\mathrm{FO}=$ fish oil, $\mathrm{DM}=$ dry matter .

\begin{tabular}{lrrrr}
\hline & \multicolumn{4}{c}{ Diet } \\
Analyzed & LA & FO & LA & FO \\
\hline DM, \% & 30.2 & 30.1 & 31.2 & 30.9 \\
$\quad$ In DM, \% & & & & \\
Ash & 7.3 & 6.6 & 6.4 & 7.4 \\
Protein & 31.1 & 33.9 & 30.8 & 35.0 \\
Fat & 29.1 & 28.6 & 30.4 & 26.9 \\
Carbohydrates $^{\text {a) }}$ & 32.5 & 30.9 & 32.4 & 30.7 \\
\hline
\end{tabular}

a) calculated as difference. cosahexaenoic (C22:6 63$)$ acids was considerably higher.

Body weights of the animals and the weights of the liver and the heart did not differ between the dietary treatments. The body weights for the mink, polecats and the raccoon dogs were on average $2249 \mathrm{~g}, 2055 \mathrm{~g}$, and $8709 \mathrm{~g}$. The average weights of the liver and (heart) were $48.6 \mathrm{~g},(10.6 \mathrm{~g}), 57.9 \mathrm{~g}$,

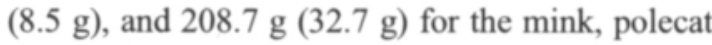
and the raccoon dog, respectively. There were no species diet interactions.

Clear species differences were found in the liver fat content and body fat composition of the animals (Table 4). Besides higher fat content in the mink livers the variation in the fat content was considerably higher for this species. Dietary background of the animals did not affect the liver fat content.

The fatty acid composition of the tissue samples strongly reflected the fatty acid profile of the dietary fats in all species and in all fat and organ samples studied (Table 4). Furthermore, interesting

Table 3. Fatty acid composition of the diets. Determination of samples taken on Nov. 30th, 1988. LA = lard diet,

$\mathrm{FO}=$ fish oil diet.

\begin{tabular}{|c|c|c|}
\hline \multirow{2}{*}{$\begin{array}{l}\text { Fatty acids } \\
\% \text { in fat }\end{array}$} & \multicolumn{2}{|c|}{ Diet } \\
\hline & LA & FO \\
\hline C14:0 & 2.5 & 5.3 \\
\hline $\mathrm{C} 16: 0$ & 26.1 & 22.8 \\
\hline C18:0 & 24.0 & 8.6 \\
\hline Saturated & 52.9 & 36.9 \\
\hline $\mathrm{C} 16: 1 \omega 7$ & 2.4 & 5.4 \\
\hline C18:1 $\omega 9$ & 33.7 & 22.6 \\
\hline $\mathrm{C} 20: 1 \omega 9$ & 1.0 & 6.6 \\
\hline $\mathrm{C} 22: 1 \omega 9+11^{1)}$ & 0.4 & 7.6 \\
\hline Monounsaturated & 37.7 & 42.8 \\
\hline $\mathrm{C} 18: 3 \omega 3$ & 0.8 & 1.3 \\
\hline $\mathrm{C} 18: 4 \omega 3$ & 0.2 & 1.7 \\
\hline $\mathrm{C} 20: 5 \omega 3$ & 0.3 & 4.2 \\
\hline $\mathrm{C} 22: 6 \omega 3$ & 0.5 & 4.3 \\
\hline Omega-3 & 1.9 & 12.3 \\
\hline $\mathrm{C} 18: 2 \omega 6$ & 7.1 & 7.5 \\
\hline $\mathrm{C} 20: 4 \omega 6$ & 0.2 & 0.2 \\
\hline Omega-6 & 7.5 & 8.0 \\
\hline
\end{tabular}

${ }^{1)}$ erucic acid (C22:1 $\left.\omega 9\right)$ and cetoleic acid (C22:1 $\left.\omega 11\right)$ not separated in the fatty acid analysis. 
Table 4. Liver fat content and the content of cetoleic, eicosapentaenoic and docosahexaenoic acids in the liver tissue, heart muscle and subcutaneous fat of the mink, polecat and the raccoon dog fed two different diets, LA = lard, FO = fish oil,

$\mathrm{ND}=$ not detected. Presented are means \pm S.D.

\begin{tabular}{|c|c|c|c|c|c|c|c|c|c|}
\hline \multirow{2}{*}{$\begin{array}{l}\text { Fatty acids } \\
\% \text { in fat }\end{array}$} & \multirow[b]{2}{*}{ LA } & \multirow{2}{*}{$\begin{array}{c}\text { Mink } \\
\text { FO }\end{array}$} & \multirow[b]{2}{*}{ LA } & \multirow{2}{*}{$\begin{array}{c}\text { Polecat } \\
\text { FO }\end{array}$} & \multicolumn{3}{|c|}{ Raccoon dog } & \multicolumn{2}{|c|}{ Significance } \\
\hline & & & & & LA & FO & Species & Diet & $\mathrm{S} \times \mathrm{D}$ \\
\hline $\begin{array}{l}\text { Liver } \\
\text { Fat \% }\end{array}$ & $\begin{array}{l}13.7 \mathrm{a} \\
\pm 4.4\end{array}$ & $\begin{array}{l}11.8 \mathrm{a} \\
\pm 7.0\end{array}$ & $\begin{array}{l}7.3 \mathrm{~b} \\
\pm 1.0\end{array}$ & $\begin{aligned} & 5.1 \mathrm{~b} \\
\pm & 0.6\end{aligned}$ & $\begin{array}{l}4.3 \mathrm{~b} \\
\pm 0.2\end{array}$ & $\begin{array}{l}4.9 \mathrm{~b} \\
\pm 0.4\end{array}$ & $<0.001$ & NS & NS \\
\hline $\mathrm{C} 22: 1 \omega 9+11^{1)}$ & $\begin{array}{l}0.2 \mathrm{~d} \\
\pm 0.0\end{array}$ & $\begin{array}{l}1.0 \mathrm{a} \\
\pm 0.1\end{array}$ & $\begin{array}{l}0.2 \mathrm{~cd} \\
\pm 0.0\end{array}$ & $\begin{array}{l}0.6 \mathrm{~b} \\
\pm 0.1\end{array}$ & $\begin{array}{l}\text { ND } \\
\text { ND }\end{array}$ & $\begin{array}{l}0.4 \mathrm{c} \\
\pm 0.0\end{array}$ & $<0.001$ & $<0.001$ & $<0.001$ \\
\hline $\mathrm{C} 20: 5 \omega 3$ & $\begin{array}{l}0.4 \mathrm{e} \\
\pm 0.1\end{array}$ & $\begin{array}{l}2.7 \mathrm{~d} \\
\pm 0.9\end{array}$ & $\begin{array}{l}2.2 \mathrm{~d} \\
\pm 0.4\end{array}$ & $\begin{aligned} & 6.7 \mathrm{~b} \\
\pm & 1.1\end{aligned}$ & $\begin{array}{l}4.1 \mathrm{c} \\
\pm 0.4\end{array}$ & $\begin{array}{l}9.3 \mathrm{a} \\
\pm 0.5\end{array}$ & $<0.001$ & $<0.001$ & $<0.001$ \\
\hline $\mathrm{C} 22: 6 \omega 3$ & $\begin{array}{l}2.9 \mathrm{~d} \\
\pm 0.6\end{array}$ & $\begin{array}{r}9.4 \mathrm{c} \\
\pm 2.2\end{array}$ & $\begin{aligned} & 8.4 \mathrm{c} \\
\pm & 1.4\end{aligned}$ & $\begin{array}{l}18.5 \mathrm{a} \\
\pm 0.9\end{array}$ & $\begin{aligned} & 8.2 \mathrm{c} \\
\pm & 1.6\end{aligned}$ & $\begin{array}{l}13.8 \mathrm{~b} \\
\pm 1.0\end{array}$ & $<0.001$ & $<0.001$ & $<0.01$ \\
\hline $\begin{array}{l}\text { Heart } \\
\text { C22:1 } \omega 9+11\end{array}$ & $\begin{array}{l}0.2 \mathrm{~d} \\
\pm 0.1\end{array}$ & $\begin{array}{l}2.5 b \\
\pm 0.7\end{array}$ & $\begin{array}{l}0.4 \mathrm{~d} \\
\pm 0.2\end{array}$ & $\begin{aligned} & 1.5 \mathrm{c} \\
\pm & 0.2\end{aligned}$ & $\begin{array}{l}0.4 \mathrm{~d} \\
\pm 0.1\end{array}$ & $\begin{array}{l}3.1 \mathrm{a} \\
\pm 0.5\end{array}$ & $<0.001$ & $<0.001$ & $<0.001$ \\
\hline $\mathrm{C} 20: 5 \omega 3$ & $\begin{array}{l}1.1 \mathrm{c} \\
\pm 0.1\end{array}$ & $\begin{array}{r}3.9 \mathrm{~b} \\
\pm 1.2\end{array}$ & $\begin{array}{r}2.9 \mathrm{~b} \\
\pm 0.7\end{array}$ & $\begin{aligned} & 7.2 \mathrm{a} \\
\pm & 0.5\end{aligned}$ & $\begin{aligned} & 1.6 \mathrm{c} \\
& \pm 0.7\end{aligned}$ & $\begin{aligned} & 8.0 \mathrm{a} \\
\pm & 1.1\end{aligned}$ & $<0.001$ & $<0.001$ & $<0.001$ \\
\hline $\mathrm{C} 22: 6 \omega 3$ & $\begin{array}{l}\quad 6.8 \mathrm{bc} \\
\pm 0.7\end{array}$ & $\begin{array}{r}7.9 \mathrm{~b} \\
\pm 1.9\end{array}$ & $\begin{array}{r}7.9 \mathrm{~b} \\
\pm 1.3\end{array}$ & $\begin{array}{l}11.4 \mathrm{a} \\
\pm 1.1\end{array}$ & $\begin{array}{l}2.2 \mathrm{~d} \\
\pm 0.6\end{array}$ & $\begin{aligned} & 5.5 \mathrm{c} \\
\pm & 0.3\end{aligned}$ & $<0.001$ & $<0.001$ & $<0.05$ \\
\hline $\begin{array}{l}\text { Subcutaneous fat } \\
\text { C22:1 } 19+11\end{array}$ & $\begin{array}{c}0.3 \mathrm{c} \\
\pm 0.1\end{array}$ & $\begin{aligned} & 3.2 \mathrm{~b} \\
\pm & 0.6\end{aligned}$ & $\begin{array}{l}0.2 \mathrm{c} \\
\pm 0.1\end{array}$ & $\begin{array}{l}3.5 \mathrm{ab} \\
\pm 0.5\end{array}$ & $\begin{array}{l}0.4 \mathrm{c} \\
\pm 0.1\end{array}$ & $\begin{aligned} & 3.9 \mathrm{a} \\
\pm & 0.3\end{aligned}$ & NS & $<0.001$ & NS \\
\hline $\mathrm{C} 20: 5 \omega 3$ & $\begin{array}{l}\text { ND } \\
\text { ND }\end{array}$ & $\begin{array}{c}0.9 \mathrm{~b} \\
\pm 0.3\end{array}$ & $\begin{array}{l}0.3 \mathrm{c} \\
\pm 0.0\end{array}$ & $\begin{array}{l}1.5 \mathrm{a} \\
\pm 0.2\end{array}$ & $\begin{array}{l}0.3 \mathrm{c} \\
\pm 0.1\end{array}$ & $\begin{array}{l}1.5 \mathrm{a} \\
\pm 0.2\end{array}$ & $<0.001$ & $<0.001$ & NS \\
\hline $\mathrm{C} 22: 6 \omega 3$ & $\begin{array}{l}0.5 \mathrm{~d} \\
\pm 0.1\end{array}$ & $\begin{array}{l}2.4 \mathrm{c} \\
\pm 1.1\end{array}$ & $\begin{array}{l}1.0 \mathrm{~d} \\
\pm 0.1\end{array}$ & $\begin{array}{l}4.2 \mathrm{a} \\
\pm 0.5\end{array}$ & $\begin{array}{l}0.9 \mathrm{~d} \\
\pm 0.3\end{array}$ & $\begin{array}{l}3.2 \mathrm{~b} \\
\pm 0.3\end{array}$ & $<0.001$ & $<0.001$ & $<0.05$ \\
\hline
\end{tabular}

a-e: means within rows having different postscripts are significantly different $(p<0.05)^{1)}$ see Table 3 .

differences between the individual fish fatty acids in their affinity to certain fat depots in different species were observed. In the FO diet, cetoleic acid accumulated especially in the heart muscle and the subcutaneous fat, while its levels in the liver fat were comparatively low. The highest levels of cetoleic acid were found in the heart and subcutaneous fat of the raccoon dogs. Moreover, in all species studied the accumulation of EPA and DHA was more prominent in the liver and heart tissue than in the subcutaneous fat. The highest levels of EPA were found in the tissues of the raccoon dogs and polecats fed the FO diet. In addition, the polecats and raccoon dogs fed the FO diet had significantly higher levels of DHA in their livers than did the mink or the corresponding animals receiving the LA diet. The DHA levels in heart were the highest in polecats fed the $\mathrm{FO}$ diet.

\section{Discussion}

Fatty acid profiles of the lard and fish oil supplemented diets differed greatly reflecting the composition of the supplemental fat. Both feed mixtures contained, however, a considerable amount of fish offal, which contributed to omega- 3 fatty acids in both diets. 
The accumulation of the polyunsaturated omega3 fatty acids was prominent in the fish oil diet for all fur animal species included in this study. There were also significant species differences, polecats and raccoon dogs having remarkably higher contents of these fatty acids in their tissues and especially in the liver than the mink. These results are in agreement with earlier studies with mink and blue fox (ROUVINEN and KIISKINEN 1989), and with blue and silver foxes (RouvinEN 1991, ROUVINEN 1992). The blue foxes fed a fish oil supplemented diet tended to concentrate more omega- 3 fatty acids in their livers than the mink (ROUVINEN and KIISKINEN 1989), while in silver fox livers the levels of these fatty acids were even higher than in blue foxes when the animals were fed the same diet (RouVINEN 1991, ROUVINEN 1992). In the earlier study (ROUVINEN 1991), the fat accumulation pattern differed between the fish oil and saturated fat diets. In the fish oil diet, the fat was present in the liver in small droplets, which was considered to be unphysiological. In addition, the degenerative change$\mathrm{s}$ observed were more numerous and severe in this dietary group (ROUVINEN 1991).

It is interesting to note that the levels of DHA in the liver and heart tissues were very high also for the LA diet. This may suggest that even very low amounts of dietary DHA will accumulate in these tissues. In addition, significant species differences could be observed with the lowest amount of DHA found in the liver of the mink, whereas in the heart the lowest amount was found in the raccoon dog. Moreover, despite equal amounts of DHA and EPA within both diets, the accumulation of DHA was in nearly all cases much more severe than of EPA. The 22 carbon chain of DHA could simply be more difficult to shorten to 16 or 18 carbons compared to EPA molecule with only 20 carbon atoms.

In the rat, dietary erucic acid and its omega-11 isomer, cetoleic acid, have been shown to cause lipid infiltration and tissue degeneration in the heart muscle (BEARE-Rogers 1977, KINSELla 1987). Several cases of unexplained cardiac failure have recently been reported in Finnish silver foxes
(SMEDS 1992). In the 1980's, during the years of intensive fox production, the dietary composition of the wet fur animal feed has changed considerably. Meat and slaughter offal based ingredients have been replaced by fish offal and industrial fish due to their more affordable price. Moreover, the use of fish oil as a cheap energy supplement has increased. It is thus reasonable to believe that there may be a connection between the accumulation of the longchained marine fatty acids, especially cetoleic acid, in the silver fox heart tissue and the pathological condition observed. Support to this hypothesis may also be found from a recent work on blue fox vixens, where long-term fish feeding prior to breeding and suckling period was shown to increase pup mortality (ROUVINEN and NIEMELÄ 1992).

The key enzymes of the peroxisomal and mitochondrial $\beta$-oxidation are the fatty acyl-CoA oxidase (FAO) and carnitine palmitoyl transferase (CPT), respectively. Their activities reflect the capacities of the corresponding oxidation pathways (MOYES et al. 1991). The peroxisomal $\beta$-oxidation is known to be induced when the diet contains high fat levels or fatty acids which are poor substrates for mitochondria (MOYES et al. 1991). In species, such as seals and salmon, which normally encounter polyunsaturated fatty acids in their diets, the mitochondria are, however, better capable to oxidize long-chained unsaturated fatty acids (MOYES et al. 1991). In the rat, feeding marine oils is known to induce the peroxisomal $\beta$-oxidation. This is considered to be the response of an omnivore to specific fatty acids which are not normally obtained in the diet. It is essentially a detoxification response (MoYes et al. 1991).

It is very likely that the differences in the accumulation of the long-chained marine fatty acids found in the present study are caused by species differences in the efficiency of the peroxisomal $\beta$ oxidation. This is apparently a consequence of adaptation to certain food sources during the evolutionary development of the different fur animal species (NELSON and ACKMAN 1988). Unlike the foxes (DEKKER 1983, FAY and STEPHENSON 1989), 
raccoon dog (MÄKELÄ and KIISKINEN 1978) and polecat (Fox 1988), the mink seems to be well capable of utilizing the long-chained polyunsaturated fatty acids due to its adaptation to a semiaquatic habitat (KYNE et al. 1989, TOLONEN 1982). Therefore, the other farm-raised carnivorous furbearers should not be fed fatty fish or fish oil in excess, since the 20 and 22 carbon-atom fatty acids are more readily accumulated in the tissues and organs of these species. The present results suggest that more emphasis should be placed on a species specific formulation of the diets for the farm-raised fur animals.

Acknowledgements. The Finnish Ministry of Agriculture and Forestry is thanked for financially supporting this study. The authors are grateful to Mr. Tapani Ratilainen, and to the staff of the Veikkola Research Farm for taking care of the animals and helping with the sampling, and to the staffs of the laboratories of the Finnish Fur Breeders Association in Vaasa, and the Institute of Animal Production, Animal Nutrition Section, in Jokioinen, for carrying out the analyses. The kind help of Mr. Steven Alward, B.Sc., in checking the English of the typescript is also greatly appreciated.

\section{References}

Beare-Rogers, J. L. 1977. Docosenoic acids in dietary fats. Progress in the chemistry of fats and other lipids 15 : 29-56.

DEKKER, D. 1983. Denning and foraging habits of red foxes, Vulpes vulpes, and their interactions with coyotes, Canis latrans, in Central Alberta, 1972-1981. Can. Field-Nat. 97: 303-306.

FAY, F. H. \& STEPHENSON, R. O. 1989. Annual, seasonal, and habitat-related variations in feeding habits of the Arctic fox (Alopex lagopus) on St. Lawrence Island, Bering Sea. Can. J. Zool. 67: 1986-1994.

Fox, J. G. 1988. Taxonomy, history, and use. In: Fox, J. G. (ed.). Biology and Diseases of the Ferret. Lea \& Febiger, Philadelphia. p. 3-13.

Kinsella, J. E. 1987. Seafoods and Fish Oils In Human Health and Disease. 317 p. Marcel Dekker Inc., New York.

KYNE, M. J., SMal, C. M. \& FaIRLeY, J. S. 1989. The food of otters Lutra lutra in the Irish midlands and a comparison with that of mink Mustela vison in the same region. Proc. R. Ir. Acad. 89B: 33-46.

Maxwell, R. J., Marmer, W. N., Zubillaga, M. P. \& DaLICKAS, G. A. 1980. Determination of total fat in meat and meat products by a rapid, dry column method. J. Assoc. Off. Anal. Chem. 63: 600-603.

MĀKelĀ, J. \& KiISKInEn, T. 1978. Supikoiran kasvatus ja ruokinta. 14 p. Suomen Turkiseläinten Kasvattajain Liitto ry,

Moyes, C. D., Suarez, R. K., Brown, G. S. \& HochachKa, P. W. 1991. Peroxisomal $\beta$-oxidation: Insights from comparative biochemistry. J. Exp. Zool. 260: 267-273.
Nelson, G. J. \& Ackman, R. G. 1988. Absorption and transport of fat in mammals with emphasis on $n-3$ polyunsaturated fatty acids. Lipids 23(11): 1005-1014.

OpStVedt, J. 1984. Fish fats. In: Wiseman, J. (ed.). Fats in Animal Nutrition. Butterworths, London. p. 53-82.

Rouvinen, K. 1991. Dietary effects of omega-3 polyunsaturated fatty acids on body fat composition and health status of farm-raised blue and silver foxes. Acta Agric. Scand. 41: 401-414.

- 1992. Effects of fish fat feeding on body fat composition of foxes. Norw. J. Agric. Sci., Suppl. 9: 249-253.

— \& KIISKINEN, T. 1989. Influence of dietary fat source on the body fat composition of mink (Mustela vison) and blue fox (Alopex lagopus). Acta Agric. Scand. 39: 279288.

— \& Niemelä., P. 1992. Long-term effects of dietary fish fatty acids on the breeding performance of blue foxes. Scientifur 16: 143-151.

SAS 1988. SAS/STAT TM User's Guide, Release 6.03 Edition. 1028 p. Cary, NC: SAS Institute Inc.

SKREDE, A. 1984. Evaluation of capelin oil as an energy source in mink diets. 3rd Int. Sci. Congr. Fur Anim. Prod., Versailles, France, Commun. Proc., Report no. 17.

— \& GulBRANDSEN, K. E. 1985. Fettkilder i pelletert tørrfồ til mink og blårev. Møde vedr. pelsdyrproduktion, NJFseminarium nr. 85, Aalborg, Denmark.

SMEDS, E. 1992. Turkiseläinten terveydentila Suomessa 1991. Turkistalous 1: 16.

TOLONEN, A. 1982. The food of the mink (Mustela vison) in north-eastern Finnish Lapland in 1967-76. Suomen Riista 29: 61-65. (In Finnish, English summary.)

ÅHMAN, G. 1965. Sojaolja som foder till mink. Våra Pălsdjur 36: 254-261. 


\section{Manuscript received July 1992}

Kirsti Rouvinen

Agricultural Research Centre of Finland

Fur Farming Research Station

SF-69100 Kannus, Finland

Present address:

Nova Scotia Agricultural College,

Department os Animal Science,

P.O.Box 550, Truro,

Nova Scotia, B2N 5E3 Canada
Jaakko Mäkelä

Finnish Fur Breeders' Association,

P.O.Box 5, SF-01601 Vantaa, Finland

Tuomo Kiiskinen

Agricultural Research Centre of Finland, Institute of Animal Production

SF-31600 Jokioinen, Finland

Seppo Nummela

Agricultural Research Centre of Finland

Central Laboratory

SF-31600 Jokioinen, Finland

\title{
SELOSTUS
}

\section{Rehun kalaperäisten rasvahappojen kertyminen eräiden lihaasyövien turkiseläinten ruhon rasvavarastoihin}

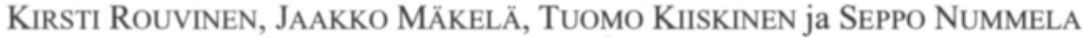 \\ Maatalouden tutkimuskeskus ja Suomen Turkiseläinten Kasvattajain Liitto ry
}

Minkeillä ja siniketuilla rehun kasviöljylisäyksen tiedetään lisäävăn linolihapon määrää ja kalaöljytäydennyksen puolestaan omega-3 rasvahappojen pitoisuutta elimistőssä. Sini- ja hopeaketuilla kalarasvaruokinnan on todettu aiheuttavan tyypillisten kalarasvahappojen, kuten ketoleeni-, eikosapentaeeni- (EPA) ja dokosaheksaeenihappojen (DHA) kertymistä nahanalaisrasvakudokseen, maksaan ja sydänlihakseen. Rehun kalarasvatäydennyksen tai erukahappopitoisen rypsiöljyruokinnan tiedetăăn myös aiheuttavan rotalla rappeutumamuutoksia sydänlihaksessa.

Tässä selostetussa tutkimuksessa selvitettiin minkin, hillerin ja supikoiran ruhon rasvakoostumusta. Eläimiä ruokittiin 5-6 kuukauden ajan joko laardilla tai kalaöljyllä täydennetyllä, kalaan ja teurasjätteeseen pohjautuvalla rehuvaliolla. Rasvalisă rehussa oli $5 \%$ tuorepainosta. Laardirehussa ketoleeni-, EPA- ja DHA-pitoisuudet olivat $0.4,0.3$ ja $0.5 \%$ rehun rasvassa. Vastaavat tasot kalaöljyrehussa olivat 7.6, 4.2 ja $4.3 \%$. Kustakin ryhmästä tutkittiin viisi eläintä. Eläimistä otettiin näytteet maksasta, sydänlihaksesta ja nahanalaisrasvakudoksesta rasvahappoanalyysiä varten.

Kaikilla tutkituilla eläinlajeilla ruhon rasvakoostumus riippui voimakkaasti rehun rasvakoostumuksesta. Kalaöljyrehulla EPA ja DHA varastoituivat erityisesti maksaan ja sydänlihakseen, kun taas ketoleenihappopitoisuudet olivat korkeimmat sydänlihaksessa ja nahanalaisrasvassa. Korkeimmat EPA-pitoisuudet analysoitiin kalaöljyrehulla ruokittujen supikoirien ja hillereiden kudoksista. Pitoisuudet vaihtelivat $6.7-9.3 \%$ maksan rasvassa ja 7.2-8.0 \% sydänlihaksen rasvassa. Minkeillä vastaavat pitoisuudet olivat ainoastaan $2.7 \%$ ja $3.9 \%$. DHA-pitoisuudet olivat korkeimmat kalaöljyllä ruokittujen hillereiden maksakudoksessa (18.5\%). Lisäksi supikoirien maksojen DHA-pitoisuudet $(13.8 \%)$ olivat merkitsevăsti minkkien arvoja korkeammat (9.4\%).

Tutkittujen pitkäketjuisten kalarasvahappojen kertyminen kudoksiin on todennäköisesti seurausta niiden riittämättömästä peroksisomaalisesta $\beta$-oksidaatiosta elimistössä. Evolutiivisen kehityksensă aikana eri eläinlajit ovat sopeutuneet parhaiten hyödyntämään tiettyjä ravintolähteitä. Puoliksi vesielämäăn sopeutuneena lajina minkki näyttää pystyvăn hyödyntämäăn kalalle tyypillisiä, pitkäketjuisia, monityydyttymăttömiä rasvahappoja muita tässă tutkittuja tarhaturkiselăimiä paremmin. Saatuihin tuloksiin perustuen kalaöljyn käyttöä rehun yksinomaisena rasvalähteenä ketun, supikoiran ja hillerin rehussa tulisi vălttäă. Enemmăn huomiota tulisi kiinnittäă myős lajikohtaiseen rehuvaliosuunnitteluun tarhatuilla turkiseläimillä. 